\title{
Challenge and opportunity research in blood supply chain management: a literature review
}

\author{
Agus Mansur ${ }^{1,2, *}$, Iwan Vanany $^{1}$, and Niniet Indah Arvitrida ${ }^{1}$ \\ ${ }^{1}$ Industrial Engineering Department, Institut Teknologi Sepuluh Nopember, Surabaya, Indonesia \\ ${ }^{2}$ Industrial Engineering Department, Universitas Islam Indonesia, Yogyakarta, Indonesia
}

\begin{abstract}
An interconnected series of the blood management is called blood supply chain management (BSCM). The stages of BSCM consisted of blood collecting, production, inventory, and distribution. The main challenges in BSCM are related to shortage, outdate, and supply chain cost which needed to minimize. Naturally, problems in BSCM are complex, it is not an easy task to find the solution. This complexity brought by several factors as follows: its inflicted risk, the uncertainty of supply and demand, blood nature as perishable commodity, demand uniqueness, and cost occurred. This research purposes was to review of various research related to BSCM and highlight opportunities to develop further research in blood supply chain (BSC). The result of this research is a suggestion on various possible future research to be explored in BSC, for example, developing an adaptive inventory model to support blood supply chain management that could be responsive toward demand fluctuation and developing collecting strategy to minimize shortage, outdate and incurred cost in supply chain level.
\end{abstract}

\section{Introduction}

Generally, blood management is a complex system. There are a lot of factors must be involved in the system. Some previous research considered health-related risk, supply availability, demand fluctuation, short blood lifetime, to the cost incurred during the process. An interconnected series of the blood management is called Blood Supply Chain Management (BSCM). The stages of BSCM consisted of blood collecting, production, inventory, and distribution [40]. The effectivity on the previous stage of BSCM will influence the future stage. Therefore, wellbeing coordination on each echelon and stakeholder in BSCM is vital to guarantee its success $[16,32,53]$.

BSCM is one of important research areas because of its value for human life. However, blood management has some special characteristics. First, blood is a commodity that regulated by strict health regulation. It is also perishable and it has tendency to mismatch between the number of blood donors (supply) and recipients (demand) [48]. Increasing the effectiveness of blood supply chain management is expected to optimize the number of blood stock. Practically, the combination of using precise planning system on blood production and well-scheduled blood donors can support the balance creation between supplier and demand. Both strategies will lessen the shortage or outdated risk [27].

Balancing the blood supply and demand is not an easy job because of the stochastic phenomenon in the supply and demand [5]. Furthermore, the richness of the blood derivatives, starting from the kind, type, rhesus, to quantity, increases the management complexity [45].
According to Kendall [45], blood is a perishable product which has limited usage lifetime. Therefore, if blood has outdated or expired, it will turn to waste. Dillon et al., [16] stated that whole blood lifetime is 35 days maximum, while Blood Red Cell and Platelet lifetime, respectively, is 21 days and 5 days.

Researchers have tried to develop blood management improvement in every aspect, including procurement, production, storage/inventory and delivery. Actually, every solution offered is not comprehensive solution and sometimes it cannot applied directly. Therefore, there are still many problems which must be solved on the upstream nor the downstream of blood supply chain.

In this case, this research will conduct literature review related to various research in BSCM. Highlighting future research chances will lead to advancement in the BSCM study. Realized or not, BSCM studies also have given benefit by supporting people welfare.

This paper relates the review of published articles from the 1960s up to 2017 , which the articles will be classified on several categories as following:

1. Blood Product Type

2.Performance Measurement

3. Hierarchy Level

4. Inventory Problem

Afterwards, this paper will focus about BSCM model in blood inventory, probabilities on its scenarios, and the importance of developing an adaptive model in blood supply chain.

\footnotetext{
Corresponding author: agusmansur@uii.ac.id
} 


\section{Blood Product Type based BSCM Research Review}

After series of laboratory tests, blood fractionation is performed. Transforming it into several types of blood product. In this research, only the dominant significant product will be discussed, which are Red Blood Cells (RBC), Blood Platelets, Plasma, Whole Blood, and Frozen Blood. Those products are the highly produced and directly transfused one. The reason why blood product type become one of this study review parts is that each blood product type has its own distinct type in function and characteristic. It leads researchers to conduct specific and focused study on one or more particular blood product type, in order to lessen the complexity of research.

Table 1. Research classification in BSCM based on product type

\begin{tabular}{|l|c|c|}
\hline \multicolumn{1}{|c|}{ Type } & Author & Count \\
\hline Red Blood Cell & $1,16,18,19,23,28,33,37,46,49$ & 10 \\
\hline Platelet & $8,10,15,20,22,27,31,43,57$ & 9 \\
\hline Plasma & $39,42,47,49$ & 4 \\
\hline Whole Blood & $11,34,39,49$ & 4 \\
\hline
\end{tabular}

\section{Performance Measurement based BSCM Review}

Research on BSCM was conducted by some researchers that focused one various performance measurement, mostly in minimization of outdate and shortage. Yet, the latest study has leaned on cost factor and other consideration. BSCM performance management that was run by researchers could be categorized as follows:

Table 3. Research classification in BSCM based on performance indicator

\begin{tabular}{|l|c|c|}
\hline \multicolumn{1}{|c|}{$\begin{array}{c}\text { Performance } \\
\text { Indicator }\end{array}$} & Author & Count \\
\hline Outdate & $\begin{array}{c}1,9,14,16,18,25,32,37,51,52,5 \\
4,58\end{array}$ & 12 \\
\hline Shortage & $\begin{array}{c}1,4,14,15,16,18,19,21,23,25,3 \\
2,37,48,51,54,58,59\end{array}$ & 17 \\
\hline $\begin{array}{l}\text { Transportation } \\
\text { Cost }\end{array}$ & $11,14,27,30,44,51$ & 6 \\
\hline Service Level & $11,26,27,30,43,44$ & 6 \\
\hline Safety & $1,3,16,18,33,36$ & 6 \\
\hline $\begin{array}{l}\text { Supply Chain } \\
\text { Cost }\end{array}$ & 16 & 1 \\
\hline
\end{tabular}

\section{Coordination Hierarchy Level based BSCM Research Review}

Researchers have been put out a various study on blood management in different hierarchy level. There is a consideration regarding urgency and depth of the study that was conducted. Hierarchy levels that commonly discussed in research are individual hospital, regional blood center level, and supply chain level.

Table 2. Research classification in BSCM based on coordination level

\begin{tabular}{|l|c|c|}
\hline \multicolumn{1}{|c|}{ Coordination } & Author & Count \\
\hline Individual Hospital & $12,17,25,41,47,55,56,60$ & 8 \\
\hline Regional Blood Center & $13,22,24,27,35,42,44,50$ & 8 \\
\hline $\begin{array}{l}\text { Supply Chain } \\
\text { Hierarchy }\end{array}$ & $6,14,20,34,49,58$ & 6 \\
\hline
\end{tabular}

\section{Blood Inventory Models Review}

Research on blood inventory problem has grown in number and variation. The nature of blood demand is uncertain. Thus creating challenges to overcome in forecasting the blood demand. In order to ease computation process, researchers would use certain distribution, like Poisson or normal distribution. Another challenge in managing the inventory could come from its perishable characteristic, where it also affected the number of wastage and cost incurred. Civelek et al. [10] tried to build protection model on platelet that was ordered by the hospital using simulation approach. As for Mole [38] had to use Markov chain approach to building relation model between a variable which served a purpose in minimizing shortage and minimizing outdate in the hospital.

Table 5. Research classification in BSCM based on Inventory Model

\begin{tabular}{|c|c|c|c|}
\hline Year & Author & Goal & Method \\
\hline 1975 & 38 & $\begin{array}{l}\text { Balancing blood stock } \\
\text { in hospital to avoid } \\
\text { wastage and shortage }\end{array}$ & $\begin{array}{l}\text { Markov } \\
\text { Decision } \\
\text { Process (MDP) }\end{array}$ \\
\hline 1979 & 11 & $\begin{array}{l}\text { Developed managerial } \\
\text { processes at each } \\
\text { level of the hierarchy } \\
\text { in a regional blood } \\
\text { bank system }\end{array}$ & Mathematical \\
\hline 1980 & 13 & $\begin{array}{l}\text { Designing } \\
\text { information systems } \\
\text { for regional blood } \\
\text { service }\end{array}$ & $\begin{array}{l}\text { Information } \\
\text { System Design }\end{array}$ \\
\hline 1982 & 39 & $\begin{array}{l}\text { Review perishable } \\
\text { inventory }\end{array}$ & Mathematical \\
\hline 2007 & 34 & $\begin{array}{l}\text { Improvement } \\
\text { procedure dan } \\
\text { outcome BSC } \\
\text { (ordering policies) }\end{array}$ & $\begin{array}{l}\text { Discrete Event } \\
\text { Simulation }\end{array}$ \\
\hline 2008 & 37 & $\begin{array}{l}\text { Build a blood } \\
\text { inventory system that } \\
\text { takes into } \\
\text { consideration the } \\
\text { demand rate }\end{array}$ & Simulation \\
\hline 2009 & 15 & $\begin{array}{l}\text { Determine order } \\
\text { period and optimum } \\
\text { order for platelet in } \\
\text { the hospital to } \\
\text { minimize the cost }\end{array}$ & $\begin{array}{l}\text { Stochastic } \\
\text { dynamic } \\
\text { programming } \\
\text { (SDP) model } \\
\text { and simulation }\end{array}$ \\
\hline
\end{tabular}




\begin{tabular}{|c|c|c|c|}
\hline 2013 & 18 & $\begin{array}{l}\text { Minimize the } \\
\text { expected system } \\
\text { outdate rate under a } \\
\text { predetermined } \\
\text { maximally allowable } \\
\text { shortage level }\end{array}$ & $\begin{array}{l}\text { Simulation } \\
\text { optimization } \\
(\mathrm{SO})\end{array}$ \\
\hline 2013 & 6 & $\begin{array}{l}\text { Evaluate and design } \\
\text { facilities and measure } \\
\text { the impact on } \\
\text { customer service }\end{array}$ & Simulation \\
\hline 2013 & 52 & $\begin{array}{l}\text { Improve blood supply } \\
\text { chain management in } \\
\text { order to use the scarce } \\
\text { resource of blood } \\
\text { more efficiently }\end{array}$ & $\begin{array}{l}\text { Discrete Event } \\
\text { Simulation }\end{array}$ \\
\hline 2013 & 29 & $\begin{array}{l}\text { Identify the optimal } \\
\text { order levels that } \\
\text { minimizes the total } \\
\text { cost, shortage and } \\
\text { wastage levels of } \\
\text { blood products at a } \\
\text { hospital. }\end{array}$ & $\begin{array}{l}\text { Integer } \\
\text { Programming }\end{array}$ \\
\hline 2014 & 19 & $\begin{array}{l}\text { Constructed inventory } \\
\text { model based on } \\
\text { optimization } \\
\text { framework simulation } \\
\text { to minimize outdate } \\
\text { rate of platelet }\end{array}$ & $\begin{array}{l}\text { Old inventory } \\
\text { ratio (OIR) }\end{array}$ \\
\hline 2015 & 10 & $\begin{array}{l}\text { A simple inventory } \\
\text { replenishment and } \\
\text { allocation heuristic to } \\
\text { minimize the } \\
\text { expected total cost } \\
\text { over an infinite time } \\
\text { horizon }\end{array}$ & $\begin{array}{l}\text { Markov } \\
\text { decision } \\
\text { process (MDP) }\end{array}$ \\
\hline 2015 & 59 & $\begin{array}{l}\text { Design a robust blood } \\
\text { supply chain system } \\
\text { to improve the blood } \\
\text { supply chain } \\
\text { efficiency }\end{array}$ & $\begin{array}{l}\text { Dynamic } \\
\text { simulation and } \\
\text { taguchi }\end{array}$ \\
\hline 2015 & 61 & $\begin{array}{l}\text { Transhipment model } \\
\text { between rescue and } \\
\text { the affected blood } \\
\text { bank by considering } \\
\text { the age of blood so as } \\
\text { to obtain a minimum } \\
\text { expired date }\end{array}$ & Simulation \\
\hline 2016 & 32 & $\begin{array}{l}\text { Design centralized- } \\
\text { based inventory } \\
\text { model and } \\
\text { collaboration of the } \\
\text { hospital to maintain } \\
\text { its inventory }\end{array}$ & $\begin{array}{l}\text { Inventory } \\
\text { model } \\
\text { approach (S-1, } \\
\text { S) }\end{array}$ \\
\hline 2017 & 46 & $\begin{array}{l}\text { Determine periodic- } \\
\text { review fixed lifetime } \\
\text { perishable inventory } \\
\text { literature by } \\
\text { considering multiple } \\
\text { independent sources } \\
\text { of supply. }\end{array}$ & $\begin{array}{l}\text { Dynamic } \\
\text { program. }\end{array}$ \\
\hline 2017 & 16 & $\begin{array}{l}\text { Determine periodic } \\
\text { review and optimum } \\
\text { order target }\end{array}$ & $\begin{array}{l}\text { Two-steps } \\
\text { stochastic } \\
\text { programming } \\
\text { approach }\end{array}$ \\
\hline
\end{tabular}

\section{Indonesia's Blood Management}

In Indonesia, only few studies are dedicated to investigate the blood management, particularly operation management and supply chain management. [62] Investigated the elevated value of average shortage and expired product in regional Red Cross (PMI), approximately $29 \%$ and $59 \%$. Discrete simulation method was used to construct the shortage and expired scenario out of several possible scenarios to decrease the shortage and expire items. They underlined several improvements that should be appointed in blood supply chain management. This research is only focused on blood production combination, which cannot determine safe blood stock that could be possibly handled by PMI.

[63] pointed the low quality of information will lead to the poor coordination among echelons in blood supply chain management. The researcher proposes traceability blood system to reinforce the coordination among echelons in blood supply chain, specifically in Indonesia. The model could show the potential benefits that will be extended from each stake holders (donor, PMI and hospital) in improving the performance in blood supply chain. The research does not provide the solution on safety stock and does not discuss the effect of behaviour alteration towards relationship pattern

A phenomenon in Indonesia's blood management that still has not been solved is its large gap related to awareness level of the donor. It is normal to find an area that has been well informed, on the other hand, also found another area that has less to none understanding regarding blood donor. This will cause the large discrepancy between blood supply from one area to another. This will cause a problem in the long run since blood demand will eventually exceed the supply. Therefore, good coordination system amongst nearby blood center will be needed

Blood demand across Indonesia could be classified into two; normal condition demand and special condition demand. The normal condition is a condition when there is no extraordinary situation that could cause a sudden spike in blood demand. A special condition is a certain condition that affects blood demand and directly spiked the blood demand, in example endemic disease outbreak such as dengue fever. It has been known that several cities in Indonesia have high potential as endemic disease area. In certain months, it is also common to have a sudden high number of a traffic accident that will obviously trigger blood demand to increase.

Based on this phenomenon, adaptive blood management model is needed. Since blood management has to be responsive to every system changes, rapidly and flexibly. Blood management is expected to be adaptive on demand fluctuation and blood supply pattern. One of the most important things to be done is strategizing blood procurement that could cater to the demand. This situation called for a study on optimum alternative blood procurement, mobile unit location determination, and arranging ideal capacity. The adaptive framework is shown in Figure 1. 


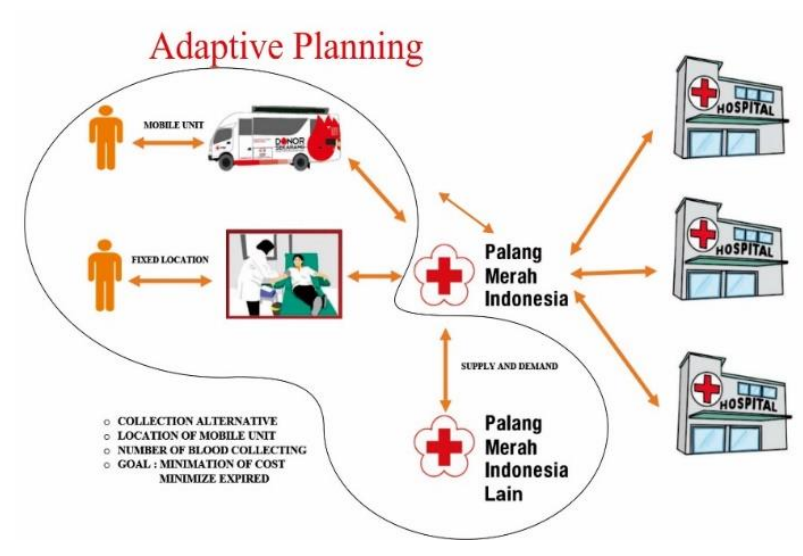

Fig 1. Adaptive planning scheme in BSCM

Adaptive planning will be affected by demand characteristic. Demand pattern changes will affect blood center's supply target level. Target level will varied, depends on demand behavior and condition, such as, whether the demand in normal, emergency or special condition.

Some research on blood inventory have been conducted by some researchers. Yet, those research have not discussed policy related flexibility level in inventory, as a writer has illustrated previously. This is an opportunity for future research to be explored more.

Even though, Dillon et al. [38] stated that he conducted optimum periodic review analysis on platelet. However, his research has not mentioned the anticipated demand changes phenomenon, so it was only focused on service level and outdate tolerance to determine inventory target level. The model above could not give a rapid response to determining optimum stock and replenishment lead time target. Opportunity to develop this research is highly possible to build inventory system by periodic review approach, considering its adaptability to supply and demand changes, to minimize the possibility of shortage and outdate.

\section{Conclusion}

Research in Blood Supply Chain can be considered as an active and dynamic study. Many studies, which appear every year, have a variety of themes, aspects and methodologies. This study presents the results of an article review in the field of the supply chain of blood from upstream to downstream with various products, differences in blood coordinate management system and performance measurement. This study also reveals research opportunities in the field of blood supply chain at the strategic level, tactical level to operational level. One of the research opportunities required is to build a reliable inventory management system, making it adaptive to environmental change

Opportunity for substantial research is still wide open, especially developing an adaptive model for blood supply chain management that could be responsive toward demand fluctuation and developing procurement strategy to minimize shortage, outdated and occurred cost in supply chain level.

\section{References}

1. B. Abbasi, S.Z. Hosseinifard, A., On the Issuing Policies for Perishable Items such as Red Blood Cells and Platelets in Blood Service, Decision Sciences 45, 995-1020 (2014)

2. E. Alfonso, X. Xie, V. Augusto, O. Garraud, Modeling and simulation of blood collection systems, Health Care Management Science 15, 63-78 (2012)

3. E. Alfonso, X. Xie, V. Augusto, P. Garraud, Modeling and simulation of blood collection systems: Improvement of human resources allocation for better cost-effectiveness and reduction of candidate donor abandonment, Vox Sanguinis 104, 225-233 (2013)

4. R.K. Bedi, K. Mittal, T. Sood, P. Kaur, G. Kaur, Segregation of blood inventory: A key driver for optimum blood stock management in a resource poor setting (2016)

5. J. Beliën, H. Force, Supply chain management of blood products: A literature review, Eur J of Opr Research 217, 1-16 (2012)

6. J. Blake, M. Hardy,Using simulation to evaluate a blood supply network in the Canadian maritime provinces, J of Enterprise Infor Manag 26, 119-134 (2013)

7. J. Blake, M. Hardy,Using simulation to evaluate a blood supply network in the Canadian maritime provinces (2013)

8. J.T. Blake, M. Hardy, A generic modeling framework to evaluate network blood management policies: The Canadian Blood Services experience, Opr Research for Health Care 3, 116-128 (2014)

9. J.F. Chapman, C. Hyam, R. Hick, Blood inventory management, Vox Sanguinis 2, 143-145 (2004)

10. I. Civilex, I. Karaesmen, A. Scheller-Wolf, Blood platelet inventory management with protection levels, Eur J of Opr Research 243, 826-838 (2015)

11. M.A. Cohen, W.P. Pierskalla, R.J. Sassetti, J. Consolo, An overview of a hierarchy of planning models for Regional Blood Bank Management, Transfusion 19, 526-534 (1979)

12. A. Coleman, O.S. Akinsola, Effective blood distribution in rural hospitals through ICT serviceoriented architecture (SOA) framework: A case study in rural hospitals in South Africa, In Studies on Ethno-Medicine 6, 141-147 (2012)

13. P.D. Cumming, K.E. Kendall, C.C. Pegels, J.P. Seagle, The impact of an information system on a regional blood service, Information and Management 3, 63-72 (1980)

14. D. Delen, M. Erraguntla, R.J. Mayer, C.N. Wu, Better management of blood supply-chain with GIS-based analytics, Annals of Opr Research 185, 181-193 (2011)

15. N.V. Dijk, J.V.D. Wal, C. Smith, Blood platelet production with breaks: optimization by SDP and simulation, 121, 464-473 (2009) 
16. M. Dillon, F. Oliveira, B. Abbasi, A two-stage stochastic programming model for inventory management in the blood supply chain A Two-Stage Stochastic Programming Model for Inventory Management in the Blood Supply Chain, J of Production Economics 187, 27-41 (2017)

17. G. Dobson, E.J. Pinker, O. Yildiz, An EOQ model for perishable goods with age-dependent demand rate, Eur J of Opr Research 0, 1-5 (2016)

18. Q. Duan, T.W. Liao, A new age-based replenishment policy for supply chain inventory optimization of highly perishable products. Int J of Prod Economics 145, 658-671 (2013)

19. Q. Duan, T.W. Liao, Optimization of blood supply chain with shortened shelf lives and $A B O$ compatibility, In Int J of Prod Economics 153, 113129 (2014)

20. H. Ensafian, S. Yaghoubi, A robust optimization model for integrated procurement, production, and distribution in platelet supply chain, Transportation Research Part E 103, 32-55 (2017)

21. B. Fahimnia, A. Jabbarzadeh, A. Ghavamifar, M. Bell, Supply chain design for efficient and effective blood supply in disasters, In Int J of Prod Economics 1-10 (2015)

22. O.S.S. Filho, M.A. Carvalho, W. Cezarino, R. Silva, G. Salviano, Demand Forecasting for Blood Components Distribution of a Blood Supply Chain, In IFAC Proceedings Volumes 46, 565-571 (2013)

23. O.S.S. Filho, W. Cezarino, G.R. Salviano, $A$ decision-making tool for demand forecasting of blood components, In IFAC Proceedings Volumes 14, 1499-1504 (2012)

24. S.M. Fortsch, E.A. Khapalova, Reducing uncertainty in demand for blood, In Opr Research for Health Care 9, 16-28 (2016)

25. B.A. Friedman, R.D. Abbot, G.W. Williams, A blood ordering strategy for hospital blood banks derived from a computer simulation, American J of Clinical Pathology 78, 154-160 (2008)

26. M.J. Galloway, G. Jane, L. Sudlow, J. Trattles, J. Watson, A tabletop exercise to assess a hospital emergency blood management contingency plan in a simulated acute blood shortage, Transfusion Medicine 18, 302-307 (2008)

27. P. Ghandforoush, T.K. Sen, A DSS to manage the platelet production supply chain for regional blood centers, In Decision Support Systems 50, 32-42 (2010)

28. A. Grasas, A. Pereira, M. Bosch, P. Ortiz, L. Puig, Feasibility of reducing the maximum shelf life of red blood cells stored in additive solution: a dynamic simulation study involving a large regional blood system, 233-242 (2015)

29. S. Gunpinar, Supply Chain Optimization of Blood Products, In A Dissertation, Departement of Industrial and Management System Engineering, University of South Florida (2013)
30. V. Hemmelmayr, K.F. Doerner, R.F. Hartl, M.W.P. Savelsbergh, Delivery strategies for blood products supplies, OR Spectrum 31, 707-725 (2009)

31. S.M. Hesse, C.R. Coullard, M.S. Daskin, A.P. Hurter, A case study in platelet inventory management, Proceedings of the 6th Ind Engineering Research Conf, 801-806 (1997)

32. Z. Hosseeinifard, B. Abbasi, The inventory centralization impacts on the sustainability of the blood supply chain, Elsevier, 1-7 (2016)

33. K. Katsaliaki, Cost-effective practices in the blood service sector, 86, 276-287 (2015)

34. K. Katsaliaki, S.C. Brailsford, Using simulation to improve the blood supply chain, $\mathrm{J}$ of the Opr Research Society 58, 219-227 (2007)

35. K.E. Kendall, A Decentralized Information Blood Management and Control System for, In the J of System and Software 1, 299-306 (1980)

36. K.E. Kendall, S.M. Lee, Formulating Blood Rotation Policies with Multiple Objectives, Manag Science 26, 1145-1157 (1980)

37. R. Kopach, B. Balcioglu, M. Carter, Tutorial on constructing a red blood cell inventory management system with two demand rates, In Eur $\mathrm{J}$ of Opr Research 185, 1051-1059 (2008)

38. R.H. Mole, Inventory Control in Hospital, 3, 461-473 (1975)

39. S. Nahmias, Perishable inventory theory: a review, Opr Research 30, 680-708 (1982)

40. A.F. Osorio, S.C. Brailsford, H.K. Smith, A structured review of quantitative models in the blood supply chain: a taxonomic framework for decisionmaking, Int J of Prod Research 1, 1-22 (2015)

41. G. Perera, C. Hyam, C. Taylor, J.F. Chapman, Hospital Blood Inventory Practice: The factors affecting stock level and wastage, Transfusion Medicine 19, 99-104 (2009)

42. C. Pitocco, T.R. Sexton, Alleviating blood shortages in a resource-constrained environment, Transfusion 45, 1118-1126 (2005)

43. G.P Prastacos, Blood inventory management: an overview of theory and practice, Manag Science (1984)

44. G.P. Prastacos, E. Brodheim, Computer-based regional blood distribution, Computers and Opr Research 6, 69-77 (1979)

45. K. Puranam, D.C. Novak, M.T. Lucas, M. Fung, Managing Blood Inventory with Multiple Independent Sources of Supply, In Eur J of Opr Research (2016)

46. K. Puranam, D.C. Novak, M.T. Lucas, M. Fung, Managing blood inventory with multiple independent sources of supply, In Eur J of Opr Research 259, 500511 (2016)

47. J. Rautonen, J. MacPherson, Redesigning supply chain management together with the hospitals, Transfusion 47, 197-200 (2007) 
48. E. Reynolds, C. Wickenden, A. Oliver, The impact of improved safety on maintaining a sufficient blood supply, Transfusion Clinique et Biologique 8, 235239 (2001)

49. J.S. Rytila, K.M. Spens, Using simulation to increase efficiency in blood supply chains, Manag Research News 29, 801-819 (2006)

50. G. Sahin, H. Sural, S. Meral, Locational analysis for regionalization of Turkish Red Crescent blood services, Comp and Opr Research 34, 692-704 (2007)

51. W.M. Smid, R. Buining, W.D. Kort, Blood supply management: experience and recommendations from the Netherlands, 50-53 (2013)

52. K.M. Spens, Using simulation to increase efficiency in blood supply chains (2013)

53. S.H.W. Stanger, Vendor managed inventory in the blood supply chain in Germany Evidence from multiple case studies, (2013)

54. S.H.W. Stanger, R. Wilding, N. Yates, S. Cotton, What drives perishable inventory management performance? Lessons learned from the UK blood supply chain, (2012)

55. S.H.W. Stanger, N. Yates, R. Wilding, S. Cotton, Blood Inventory Management: Hospital Best Practice, In Transfusion Medicine Reviews 26, 153163 (2012)

56. R.W. Toner, L. Pizzi, B. Leas, S.K. Ballas, A. Quigley, N.I. Goldfarb, Costs to hospitals of acquiring and processing blood in the US: A survey of hospital-based blood banks and transfusion services, Applied Health Economics and Health Policy 9, 29-37 (2011)
57. L.M. Williamson, D.V. Devine, Challenges in the management of the blood supply, In the Lancet 381, 1866-1875 (2013)

58. E. Yuzgec, Y. Han, N. Nagarur, A simulation model for blood supply chain systems, In IIE Annual Conference and Expo, 1703-1711 (2013)

59. S.M. Zahraee, J.M. Rohani, A. Firouzi, A. Shahpanah, Efficiency Improvement of Blood Supply Chain System Using Taguchi Method and Dynamic Simulation, Procedia Manufacturing 2,1-5 (2015)

60. E.D. Zepeda, G.N. Nyaga, G.J. Young, Supply chain risk management and hospital inventory: Effects of system affiliation, In $\mathrm{J}$ of Opr Manag 44, 30-47 (2016)

61. K.M Wang, Z.J Ma Age-based policy for blood transshipment during blood shortage, Transportation Research Part E 80 ,166-183, (2015)

62. A.W. Suwardie, B.M.Sopha, M.K. Herliansyah, A Simulation Model of Blood Supply Chain at Indonesian Regional Red-Cross, Proceedings of The 2013 International Conference on Logistics and Maritime Systems (2013).

63. I. Vanany, A. Maryani, B. Amaliah, F. Rinaldy, F. Muhammad, Blood traceability system for Indonesian blood supply chain, Procedia Manufacturing 4, 535-542, ( 2015 ) 